\title{
FPS/WWF Revolving Fund: Final Report
}

The Joint Revolving Fund of the Fauna Preservation Society and the World Wildlife Fund was set up by agreement between the FPS and WWF International in 1966. Its aim was to enable urgent conservation projects to be financed quickly without having to go through the usual committee procedure. Under the agreement WWF agreed to repay sums advanced out of the Revolving Fund, 50 per cent of each grant within a year and the remainder when sufficient funds were available.

The FPS put $\mathfrak{f} 4516$ from its capital into the Fund to provide an initial balance, and also received donations totalling $£ 7775$. By the time the Fund came to be wound up at the end of 1970 (to be succeeded, as far as the FPS is concerned, by the Oryx 100\% Fund), a total of 36 WWF projects had been aided to a total amount of nearly $£ 38,000$. Of this total $£ 2917.50$ was converted into outright grants by FPS, and the remainder was refunded by WWF under the agreement. When the Fund came to an end the Society's original capital was reinvested and the balance of $£ 6277$ (including earmarked grants totalling $£ 2200$ ) handed over to form the initial balance of the Oryx $100 \%$ Fund.

The following outright grants were made by FPS:

$\begin{array}{lc} & £ \\ \text { Abuko Reserve, The Gambia (fencing) } & 1000 \\ \text { Landrover for Pakistan WWF } & 500 \\ \text { Moroccan Tortoise Survey } & 400 \\ \text { Persian Fallow Deer } & 330 \\ \text { Ceylon Elephant Survey } & 291.50 \\ \text { Cousin Island, giant tortoises } & 230 \\ \text { Great Abbai Expedition, Ethiopia } & 100 \\ \text { Ethiopian Forest Survey } & 66 \\ & £ 2917.50\end{array}$

During the five years in which the Revolving Fund operated, the following endangered species were aided: aye-aye (Madagascar), mountain gorilla, brown bear, Ceylon elephant, dugong, Javan and Sumatran rhinos, Somali wild ass, kouprey, tamaraw, Persian fallow deer, jackass penguin, Japanese crested ibis, Swinhoe's pheasant, North African land tortoise, and Nile crocodile. The Fund benefited conservation in the following countries:

Africa: Aldabra, Ethiopia, Ghana, Madagascar, Morocco, Seychelles, South Africa, The Gambia, Uganda, Zambia.

Asia: Cambodia, Ceylon, Indonesia, Japan, Jordan, Malaysia, Pakistan, Philippines, Taiwan.

Europe: Italy.

South America: Ecuador (Galapagos), Peru. 